\title{
ELECTRICAL STIMULATION IN REHABILITATION OF THE PATIENTS WITH FACIAL NERVE PARALYSIS
}

\section{Methodist R.Almanienè - speech therapist, S.Raginienè - speech therapist}

Vilnius University Hospital Santaros Klinikos, Centre of Rehabilitation, Physical and Sports Medicine - Vilnius, Lithuania

\begin{abstract}
Background Facial nerve paralysis is treated by speech therapist- face mimic, lip, cheeks muscles training and electrical stimulation. Electrical stimulation procedures are done during individual session, using all methods at the same time for the correction of facial nerve paralysis. The usage of electrical stimulation by VocaStim device is method in logopedic therapy and little is known about its effect for the patients with facial nerve paralysis.
\end{abstract}

Objective The purpose of this study was to evaluate the effectiveness of electrical stimulation for patients with facial nerve paralysis.

Methods The treatment group consists of 50 patients with facial nerve paralysis. The functioning of mimic, lip, cheeks muscles was evaluated before starting the logopedic training and after the treatment. During the treatment the upper and lover mimic muscles was evaluated of 6-point grading system. All the methods of correct face mimic, lip, cheeks 2,5 mucsles training were used: face mimic, lip, cheeks muscles articuliation exercise, lips sound pronunciation adjustment, face symmetry reconstruction, adjustment ready. 25 patients of the treatment group had 1,5 electrical stimulation procedures using VocaSTIM device. At admission the patients were devided into 2 groups, where there was no differences in their level of violation and the avarage age. Stimulation is electric (constant or pulse electric current), acoustic (playback of recorded sounds) and optical (the patient is provided with postcard-sized sheets with sounds).
Results The study was conducted to evaluate the benefits of electrical stimulation for patients with facial nerve paralysis. Data gathering period was from 2014 to 2017, average age of the patients $-53,52$ years. After the logopedic treatment facial nerve functions were improved in both groups. However, the facial nerve functions of the group treated by electrical stimulation were better than the other group that was treated by facial nerve training alone.

Conclusions Electrical stimulation is beneficial to the recovery of facial nerve paralysis.

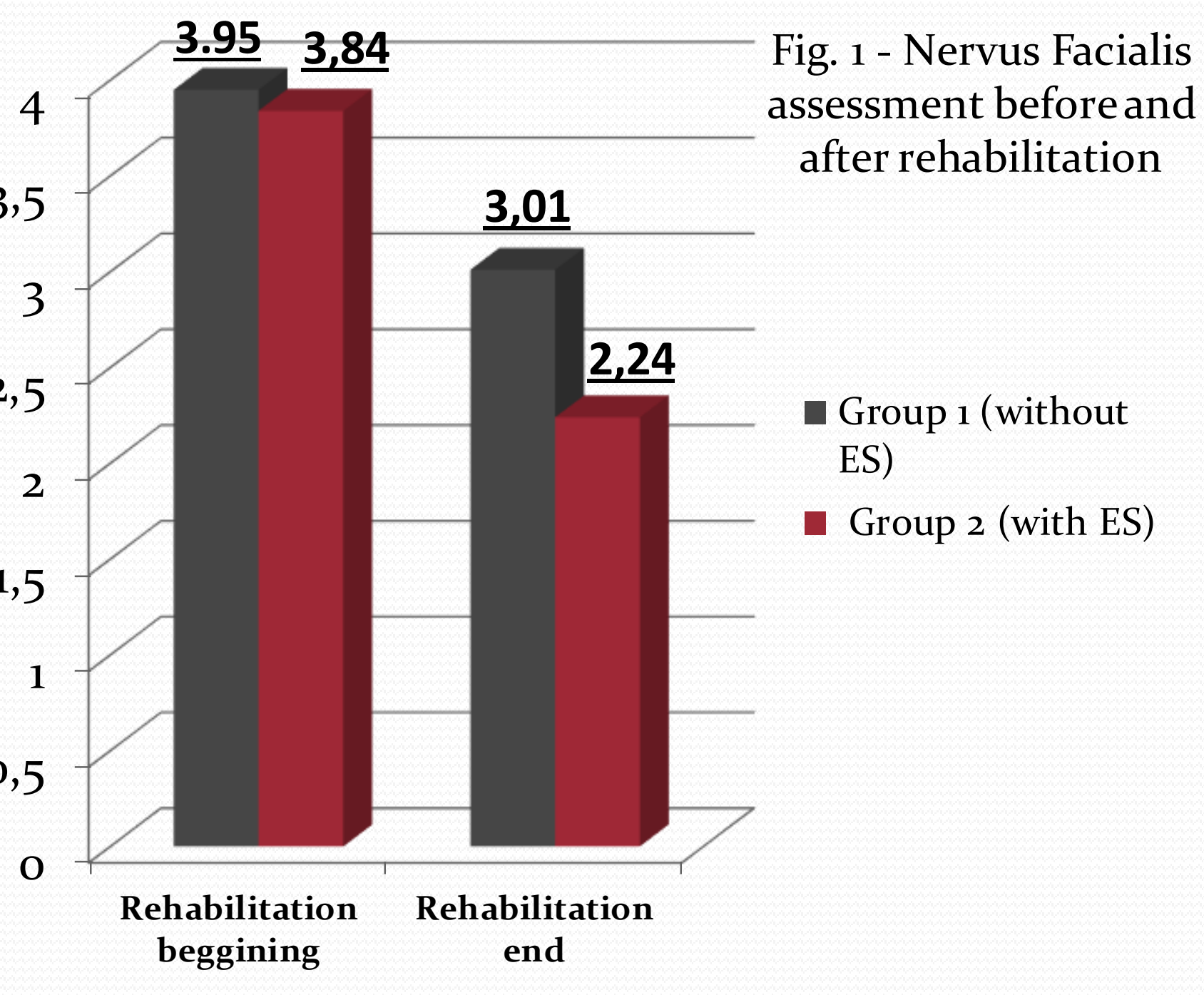

\begin{tabular}{|c|c|c|c|c|c|c|}
\hline & Grade I & Grade II & Grade III & Grade IV & Grade V & $\begin{array}{c}\text { Grade } \\
\text { VI }\end{array}$ \\
\hline & Normal & Slight Dysfunction & Moderate Dysfunction & $\begin{array}{l}\text { Moderate Severe } \\
\text { Dysfunction }\end{array}$ & Severe Dysfunction & \begin{tabular}{|c|} 
Total \\
Paralysis
\end{tabular} \\
\hline Gross: & $\begin{array}{c}\text { Normal } \\
\text { facial } \\
\text { function in } \\
\text { all areas }\end{array}$ & $\begin{array}{c}\text { slight weakness } \\
\text { noticeable on close } \\
\text { inspection; may have } \\
\text { very slight synkinesis }\end{array}$ & $\begin{array}{l}\text { obvious but not disfiguring } \\
\text { difference between two sides; } \\
\text { noticeable but not severe } \\
\text { synkinesis, contracture, and/or } \\
\text { hemi-facial spasm }\end{array}$ & $\begin{array}{c}\text { obvious weakness } \\
\text { and/or disfiguring } \\
\text { asymmetry }\end{array}$ & $\begin{array}{c}\text { only barely } \\
\text { perceptible motion }\end{array}$ & $\begin{array}{c}\text { No } \\
\text { movement }\end{array}$ \\
\hline At rest: & & $\begin{array}{l}\text { normal symmetry and } \\
\text { tone }\end{array}$ & normal symmetry and tone & $\begin{array}{c}\text { normal symmetry } \\
\text { and tone }\end{array}$ & asymmetry & \\
\hline$\underline{\text { Motion }}$ & & $\begin{array}{l}\text { forehead - moderate to good } \\
\text { function; eye - complete } \\
\text { closure with minimum effort; } \\
\text { mouth - slight asymmetry }\end{array}$ & $\begin{array}{c}\text { forehead - slight to moderate } \\
\text { movement; eye - complete closure } \\
\text { with effort; mouth - slightly weak } \\
\text { with maximum effort }\end{array}$ & $\begin{array}{l}\text { forehead - none; eye - } \\
\text { incomplete closure; } \\
\text { mouth - asymmetric with } \\
\text { maximum effort }\end{array}$ & $\begin{array}{c}\text { forehead - none; eye - } \\
\text { incomplete closure; } \\
\text { mouth - slight } \\
\text { movement }\end{array}$ & \\
\hline
\end{tabular}

